\title{
JAK3 Gene Mutation
}

National Cancer Institute

\section{Source}

National Cancer Institute. AKK3 Gene Mutation. NCI Thesaurus. Code C136647.

A change in the nucleotide sequence of the JAK3 gene. 